\title{
Lisääntyvät kasvinsuojeluriskit ja niiden hallinta ilmaston muuttuessa
}

\author{
Kari Tiilikkala ${ }^{1)}$, Asko Hannukkala ${ }^{1)}$, Jukka Salonen $^{1)}$, Erja Huusela-Veistola ${ }^{1)}$, Pauliina Laitinen ${ }^{1)}$, Hannu \\ Ojanen $^{1)}$ ja Sini Ooperi ${ }^{2)}$ \\ ${ }^{1)}$ MTT Kasvintuotannontutkimus, 31600 Jokioinen, etunimi.sukunimi@mtt.fi \\ ${ }^{2)}$ Soveltavan biologian laitos, Helsingin yliopisto, Latokartanonkaari 9, PL27, 00014 Helsingin \\ yliopisto, sini.ooperi@helsinki.fi
}

\section{Tiivistelmä}

Ilmaston muutoksella on monia vaikutuksia kasvintuhoojien menestymiseen ja vahingollisuuteen Suomessa. Viljelyn ja riskien muuttuessa myös torjunta muuttuu monella tavalla. Kasvinsuojeluriskien kasvu on alkanut jo ja odotettavissa on "kolme riskiaaltoa". Ensimmäisenä voivat näkyä lämpötilan ja kosteuden muutosten suorat vaikutukset. Toinen "riskiaalto" liittyy syyskylvöisten kasvien ja ympärivuotisen viljelyn yleistymiseen. Monet tuhoojat voivat jatkaa aktiivivaiheen kehitystä ympärivuotisesti. Populaatiokoot moninkertaistuvat ja vastaavasti tuhoojien aiheuttamat haittavaikutukset lisääntyvät. Kemiallisen torjunnan painopiste alkaa siirtyä keväästä ja kesästä syksyyn. Kolmas "riskiaalto" liittyy täysin uusien viljelykasvien tuloon ja niitä seuraavien uusien kasvintuhoojien kotiutumiseen Suomeen. Puutarhatuotannossa taimituonti nopeuttaa riskien kasvua olennaisesti jo nyt.

Ilmaston muutoksesta hyötyviä tuholaisia ovat mm. kirvat, punkit ja ankeroiset, jotka lisääntyvät niin pitkään kuin kasvustoissa on niille sopivaa ravintoa. Lämpösumman kasvu avittaa myös monen tulokaslajin juurtumista Suomeen. Syksyn muutoksesta hyötyviä tuholaisia ovat esim. etanat ja monet kärpäset. Kirvojen runsastumiseen liittyy merkittävä virustautien levintäriski. Lämpö ja kosteusjaksojen lisääntyminen suosivat useimpia kasvitauteja ja pitenevä kasvukausi altistaa kasvit pidempään taudinaiheuttajille. Eniten kasvitautien lajikirjoa avomaalla tulee muuttamaan siirtyminen kevätmuotoisista viljoista ja öljykasveista syysmuotoihin. Muuttuva ilmasto tulee suosimaan erityisesti viljojen ruoste- ja härmätauteja, jotka nykyisin ovat meillä melko satunnaisia. Syysohran viljely mullistaa ohranhärmän epidemioiden dynamiikan täysin. Lämpenevät säät ja lisääntyvä kosteus hyödyttävät monia bakteeritauteja, fytoplasmoja, viruksia ja niiden vektoreita, joista voi koitua lisääntyvää riesaa niin viljoille, perunalle kuin puutarhakasveille. Rikkakasveista kilpailukykyään nopeimmin lisäävät rikkaheinät. Syyskylvöisten kasvien viljelyn laajentuminen nostaa syysitoisten 1-vuotisten rikkakasvien merkitystä.

Tulevaisuudessa kasvinsuojeluriskien hillintä perustuu entistäkin enemmän kotimaisen ja terveen lisäysmateriaalin käyttöön joten terveen lisäysmateriaalin tuotantokapasiteetti pitää säilyttää. Samoin taudinkestävien lajikkeiden jalostus pitää turvata riittävällä resursoinnilla. Riskimuutosten seurantaan tarvitaan systemaattinen tarkkailujärjestelmä ja tehokas tiedonvälitys. Torjuntatarpeen ajoituksen muuttuessa kasvinsuojeluaineiden ruiskutus siirtyy syksyyn ja kasvinsuojelusta aiheutuvat ympäristöriskit lisääntyvät. Panostus biologiseen torjuntaan ja ekosysteemipalvelujen tuntemiseen on välttämätöntä, jos halutaan välttää kasvinsuojelusta tai sen epäonnistumisesta aiheutuvat riskit. Viljelyjärjestelmien kehittämisessä ja maankäytössä on painopiste siirrettävä kesäkaudesta talveen, koska talvikauden biologiset prosessit muuttuvat eniten. Onnistunut sopeutuminen talvikauden muutoksiin ratkaisee riskienhallinnan kokonaisuuden.

\footnotetext{
Asiasanat

Ilmaston muutos, kasvinsuojelu, IPM, PRA, torjunta-aineiden käyttö, ympäristöriskit, NAP, tulokaslajit, CLIMEX
} 


\section{Johdanto}

Ilmastonmuutos Suomessa ilmenee lähinnä lämpötilan nousuna ja sadannan muuttumisena. Maatalouden ja kasvintuotannon kannalta positiivisena on pidetty kasvukauden pitenemistä. Ilmastonmuutos voi kuitenkin parantaa kasvintuhoojien elinolosuhteita ja lisätä kasvinsuojelutarvetta.

Ensimmäiset tiedot ilmaston muutoksesta ja sen vaikutuksista kasvinsuojeluriskeihin Suomessa on julkaistu laajana hankeraporttina 1996 (Carter ym. 1996, Mela ym. 1996). Se ja jo aikaisemmat tutkimukset ovat osoittaneet ilmaston lämpenemisen parantavan kasvintuhoojien kehitystä ja vahingollisuutta Suomessa (Tiilikkala 1991). Kaukoranta (1996) arvioi jo viisitoista vuotta sitten, että keskilämpötilan nousu 1 asteella lisää kasvitautien torjuntatarvetta yhdellä ruiskutuskerralla per kasvukausi. Viimeaikaiset tulokset ja tilastot osoittavat ennustetun torjuntalisäyksen toteutuvan (Hannukkala ym. 2007, Evira 2009). Katsaus tärkeimmistä torjuntakohteista julkaistiin Itämeren alueen yhteistyönä vuonna 2001 (Salonen ym. 2001) Maa- ja puutarhatalouden lisäksi kasvien terveysriskien on todettu lisääntyvän myös metsänsuojelussa (Päivinen 2007, Vanhanen 2008) ja hyönteisvälitteisten elintautien yleistyminen on havaittu tuotantoeläinten tautitutkimuksissa (Lindgren \& Gustafson 2007).

Käytännön kasvinsuojelun ja tutkimuksen kannalta oman haasteensa tuo EU:n ympäristöpolitiikka ja sen tavoitteet vähentää torjunta-aineiden käytöstä johtuvia ympäristöhaittoja (Commission of the European communities 2006, The European Parliament and the Council 2009a ja 2009b).

Tässä julkaisussa esitettävät tulokset liittyvät MTT:n johtamaan tutkimukseen: ”Ilmastonmuutokseen sopeutuminen maa- ja elintarviketaloudessa" (ILMASOPU). Tutkimuksen ja riskinarvioinnin lähtökohtana on ollut kokonaisuus, jossa suorien ilmastovaikutusten lisäksi lähtötietoina käytetään hankkeen muissa osissa tuotettua viljelytietoa, skenaarioita sekä ympäristön tilaan liittyviä muutostietoja. Tutkimuksen erityistavoitteena oli osoittaa jo tapahtunut muutos, mallinnukseen perustuvat skenaariot sekä viljelyjärjestelmien kehitykseen liittyvät muutokset. ILMASOPU -hankkeen tavoitteiden mukaisesti esitämme myös ehdotukset päätöksiksi, joita tarvitaan riskien minimoinnissa ja torjuntatarpeen ennakoinnissa.

\section{Aineisto ja menetelmät}

\section{DATA perusteinen arviointi}

Tutkimuksemme ensimmäisessä vaiheessa hankittiin tiedot jo tapahtuneesta riskien muutoksesta, joka on todettu Itämeren ympärysmaissa. Tutkimus tehtiin NJF:n tutkijayhteistyönä, ja tulokset on julkaistu Maataloustieteen Päivillä vuonna 2008 (Tiilikkala ym. 2008).

\section{Mallinnukseen perustuva työ}

Mallinnuksissa käytettiin Climex- ohjelmistoa (Sutherst ym. 2004) ja säädatana FinAdapt -aineistoa, joka oli ILMASOPU-hankkeen käytössä. Mallinnettuja tuholaisia olivat koloradonkuoriainen (Leptinotarsa decemlienata) ja maissikoisa (Ostirinia nubilalis). Ilmaston muutoksen vaikutusta kolmannen trofiatason eliöihin simuloitiin kukkakärpäsen (Episyrphus balteatus) sukupolvien määrää osoittaneella CLIMEX analyysillä. Analyyseissä käytetyt parametrit olivat:

D. cemlineata (venäläisen populaation parametrit/Sini Ooperi): $\mathrm{DV} 0=10^{\circ} \mathrm{C}, \mathrm{DV} 3=28{ }^{\circ} \mathrm{C}, \mathrm{PDD}=428,1$

O. nubilalis: parametrit saatavissa tutkija Eva Kocmánkoválta (Mendel University of Agriculture and

Forestry, Institute of Landscape Ecology, Zemedelska 1, 61300 Brno, Czech Republic)

E.balteatus: DV0 $=6.8^{\circ} \mathrm{C}, \mathrm{DV} 1=14^{\circ} \mathrm{C}, \mathrm{DV} 2=20^{\circ} \mathrm{C}, \mathrm{DV} 3=30^{\circ} \mathrm{C}, \mathrm{PDD}=374$ (Hart ym.1997)

\section{Asiantuntija-arvioinnit}

MTT:n tietokannoissa oleva tieto sekä käynnissä olevien hankkeiden data analysoitiin asiantuntijaryhmässä, johon kuuluivat: Asko Hannukkala, Marja Jalli, Päivi Parikka, Peppi Laine, Anne Lemmetty, Satu LatvalaKilby, Jukka Salonen, Heikki Jalli, Terho Hyvönen, Pentti Ruuttunen, Kari Tiilikkala, Erja HuuselaVeistola, Anne Nissinen, Irene Vänninen, Jarmo Ketola, Irmeli Markkula, Tuomo Tuovinen, Hannu Ojanen, Pauliina Laitinen, Sirpa Kurppa, Pirkko Laitinen. Riskinarvioinnissa sovellettiin kansainvälisiä standardeja ja ISPM 11 periaatteita (FAO 2006), mutta lajikohtaisia riskinarviointeja (PRA) ei tehty. Dataanalyysiin perustuvat arviot on koottu vuodenajoittain jaoteltuun taulukkoon.

\section{Ympäristöriskit, torjunta-aineet vesissä}

Tässä tutkimuksessa tehdyt torjunta-aineiden käytön muutosarviot perustuvat torjunta-aineiden kansalliseen myyntitilastoon (Evira 2009), Pirkko Laitisen väitöstyöhön (Laitinen 2009) sekä MTT:n ja SYKE:n 
tutkimuksiin (Hannukkala ym. 2007, Ruuttunen ja Laitinen 2008). Ympäristöriskeihin liittyvät tulokset esitetään ILMASOPU - hankkeen ympäristöpäästöjä ja viljelyn muutoksia esittävissä osissa ja julkaistaan samanaikaisesti tämän kirjoituksen kanssa (Maataloustieteen Päivät 2010).

\section{Tulokset ja tulosten tarkastelu}

Kasvinsuojeluriskien kasvu on jo alkanut ja odotettavissa on "kolme riskiaaltoa". Ensimmäisenä voivat näkyä lämpötilan ja kosteuden muutosten suorat vaikutukset, jotka nopeuttavat monen organismin kehitystä, lisääntymistä sekä vahingollisuutta. Myös talvehtimisessa voi tapahtua suuria muutoksia. Toinen "riskiaalto" liittyy syyskylvöisten kasvien ja ympärivuotisen viljelyn yleistymiseen. Kolmas "riskiaalto" ajoittuu täysin uusien viljelykasvien tuloon ja niiden kasvintuhoojien kotiutumiseen Suomeen. Tuontitaimia käyttävässä puutarhatuotannossa riskien kasvu voi olla erityisen nopeaa. Esimerkit tulevaisuuden riskeistä on esitetty taulukossa 1.

Taulukko 1. Tulevaisuuden kasvinsuojeluriskit vuodenajoittain luokiteltuina esimerkkeinä.

\begin{tabular}{|c|c|c|c|}
\hline $\begin{array}{l}\text { Vuoden- } \\
\text { aika }\end{array}$ & $\begin{array}{l}\text { Muutokseen vaikuttavat } \\
\text { tekijät (viljelytekniikan } \\
\text { muutos) }\end{array}$ & Ryh & Esimerkkejä hyötyjistä \\
\hline Kevät & $\begin{array}{l}\text { Kevään aikaisuus, } \\
\text { kuivuus, valo } \\
\text { (talvikasvit avomaalla, } \\
\text { tunnelitekniikat) }\end{array}$ & $\begin{array}{l}\text { Hyönteis- } \\
\text { tuholaiset } \\
\text { Kasvitaudit } \\
\text { Rikat }\end{array}$ & $\begin{array}{l}\text { Aikuisina talvehtivat hyönteiset, kirpat, punkit, ankeroiset, } \\
\text { taimivaiheen tuholaiset } \\
\text { Möhöjuuri, omenarupi, ruosteet, härmät, marjakasvien ja } \\
\text { viljojen lehtilaikkutaudit, tyvilaikku ja muut viljojen tyvitaudit } \\
\text { Juolavehnä, jauhosavikka, saunakukka, voikukka }\end{array}$ \\
\hline Kesä & $\begin{array}{l}\text { Lämpötilat, } \\
\text { lämpösumma sekä } \\
\text { rankkasateet ja lako, } \\
\text { (uudet lajikkeet ja } \\
\text { viljelykasvit) }\end{array}$ & $\begin{array}{l}\text { Hyönteis- } \\
\text { tuholaiset } \\
\text { Kasvitaudit }\end{array}$ & $\begin{array}{l}\text { Useita sukupolvia tuottavat tuholaiset (kirvat!), virusvektorit, } \\
\text { tulokaslajit, punkit, ankeroiset, ripsiäiset, viljakukko } \\
\text { Vektorilevintäiset fytoplasma- ja virustaudit BYDV, PVY, } \\
\text { tummarengasmätä, Pectobacterium- ja Dickeya- } \\
\text { bakteeritaudit, 'uudet' Phytopthora- ja Fusarium-lajit, härmät, } \\
\text { ruosteet } \\
\text { Peltovalvatti, C-4 kasvit (esim. kanahirssi, revonhäntä, } \\
\text { viherpantaheinä) kierumatara (peltomataran rinnalle) }\end{array}$ \\
\hline Syksy & $\begin{array}{l}\text { Hämäryys, märkyys, } \\
\text { lämpö vaatimattomille } \\
\text { organismeille } \\
\text { (syyskylvö) }\end{array}$ & $\begin{array}{l}\text { Hyönteis- } \\
\text { tuholaiset } \\
\text { Kasvitaudit }\end{array}$ & $\begin{array}{l}\text { Etanat, kahukärpäset, kaalikärpäset, nisäkkäät, punkit, kirvat, } \\
\text { hesseninsääski, viirukaskas/WDV } \\
\text { Syysviljoja syksyllä vaurioittavat taudit (tyvilaikku, härmät, } \\
\text { ruosteet), varastotaudit (Pythium- ja punamätä perunalla, } \\
\text { vihannesten varastotaudit) } \\
\text { Syysitoiset 1-vuotiset rikkakasvit (esim. saunakukka } \\
\text { peltolemmikki, linnunkaali) ja siemenlevintäiset rikkaheinät } \\
\text { (mm. kylänurmikka kattarat, luoho, timotei) }\end{array}$ \\
\hline Talvi & $\begin{array}{l}\text { Leutotalvisuus, } \\
\text { sateisuus, lilluvedet ei } \\
\text { pakkasia, sienet ja } \\
\text { maamikrobit aktiivisia } \\
\text { Syysmuotoisten } \\
\text { viljelykasvien luoma } \\
\text { talvihabitaatti }\end{array}$ & $\begin{array}{l}\text { Hyönteis- } \\
\text { tuholaiset } \\
\text { Kasvitaudit } \\
\text { Rikat }\end{array}$ & $\begin{array}{l}\text { Tulokaslajit, aktiivivaiheessa säilyvät ja/tai munina talvehtivat } \\
\text { tuholaiset, virusvektorit, etanat, jyrsijät, kasvihuoneesta } \\
\text { karanneet tuholaiset } \\
\text { Härmät, ruosteet, lehtibakterioosit, jääntiviljoissa ja } \\
\text { jääntiperunassa säilyvät taudit } \\
\text { Syysitoiset 1-v rikkakasvit (ks. syksy) juolavehnä ja muut } \\
\text { rikkaheinät kuten puntarpäät ja röllit }\end{array}$ \\
\hline
\end{tabular}

\section{Tuholaiset}

Ilmaston muutoksen vaikutukset tuhohyönteisiin ilmenevät pääosin kolmella tavalla: levinneisyysalueiden, esiintymisajankohdan ja runsauden muutoksina. Ilmastonmuutoksen varautumisessa on huomioitava niin uudet tuholaislajit kuin vanhojen tuttujen lajien erilainen esiintymisaika ja nopeampi kehitysrytmi. Kasvintuhoojan merkityksen kannalta tärkeintä on ajoitus: miten hyvin tuholaisen esiintymishuippu synkronoi viljelykasvin alttiin kehitysvaiheen kanssa. Esimerkkejä kasvukauden aikaisen lämpötilan ja lämpösumman vaikutuksista hyönteisten kotiutumiseen ja lisääntymiseen on esitetty kuvissa 1, 2 ja 3. 

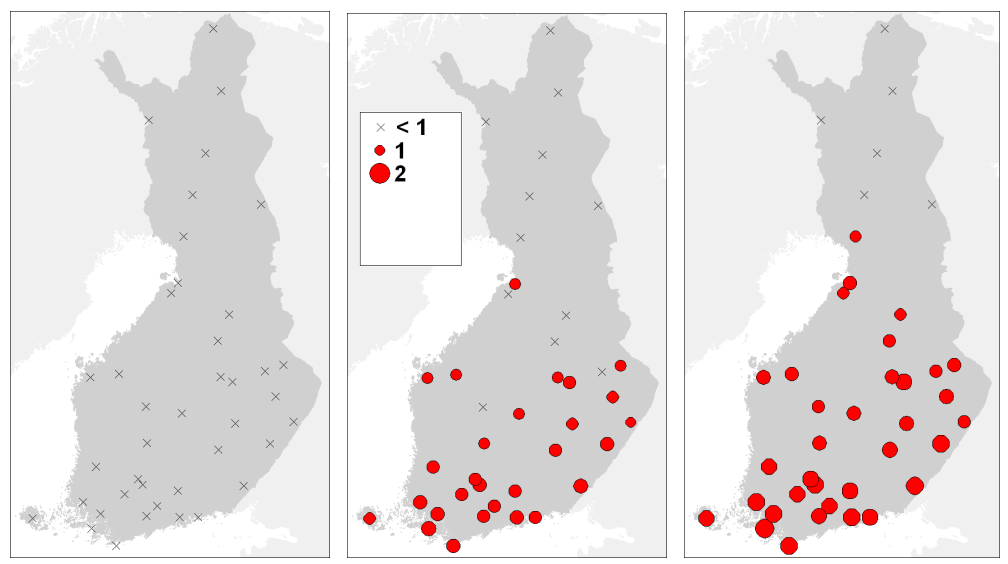

Kuva 1. Koloradonkuoriaisen sukupolvien määrä/kasvukausi nykyilmastossa 1971-2000 (vasen kuva), ns. eteläisen populaation sukupolvien määrä 2021-2050 (keskellä) ja Venäjällä kylmään sopeutuneen populaation sukupolvien määrä 2021-2050 (oikeanpuoleinen karttakuva), x = ei yhtään sukupolvea, suurin mallin tuottama arvo oli 1,81 Turussa.
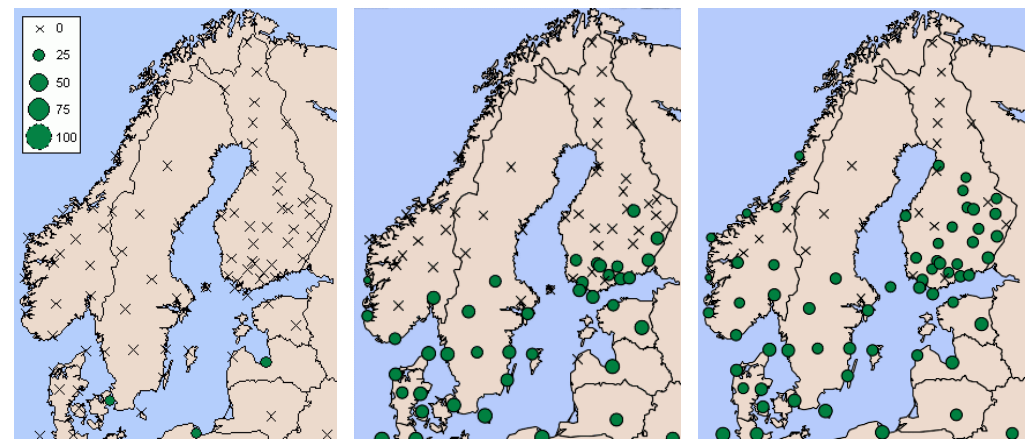

Kuva 2. Maissikoisan kotiutumisindeksi = 0 nykyilmastossa (1971-2001) (kuva vasemmalla). CLIMEX-mallin mukaan laji voisi kotiutua Etelä-Suomeen 2021-2050, jos saapuvan populaation kehityksen kynnyslämpötila on +10 ${ }^{\circ} \mathrm{C}$ (keskellä) ja Oulun korkeudelle, jos kynnyslämpötila on $+8{ }^{\circ} \mathrm{C}$ (kuva oikealla).

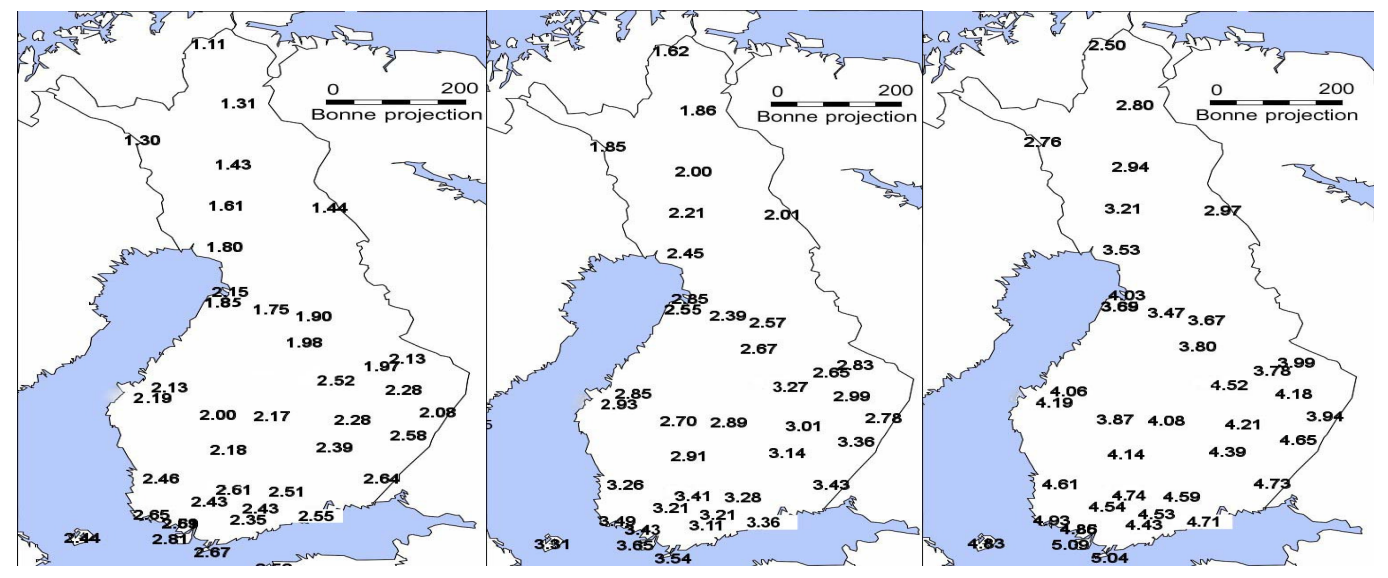

Kuva 3. Kirvoja syövän kukkakärpäsen sukupolvien määrä/kasvukausi nykyilmastossa FinAdapt 1971-2000 (vasen kuva), FinAdapt 2021-2050 A2-skenaarion toteutuessa (keskikuva) ja FinAdapt 2070-2099 A2:n toteutuessa (oikealla). CLIMEX-mallinnus osoitti, että myös torjuntaeliöt hyötyvät ilmaston muutoksesta.

Uudet viljelykasvit ja lajikkeet voivat tuoda mukanaan kokonaan uuden habitaatin tai isäntäkasvin, ja luoda täten pohjan uusille kasvintuhoojaongelmille. Uusista viljelykasveista tyyppiesimerkki on maissi, jonka 
tuholaiset ja taudit todennäköisesti kotiutuvat Suomeen maissin viljelyn yleistymisen myötä. Myös syysmuotoisten viljojen ja öljykasvien viljelyn lisääntyminen muuttaa tuholaispaineen ajoitusta. Vaikutukset voivat ilmetä myös kasvukauden ulkopuolella ja välillisesti. Esimerkiksi Englannissa on havaittu perunan Y-virusta levittävän persikkakirvan hyödyntävän talvihabitaattinaan syysrapsia (Cocu ym. 2005). Monet tekijät tukevat sitä oletusta, että kirvalevintäisten virustautien aiheuttamat riskit voivat lisääntyä nopeasti (Harrington 2007).

Koska eri lajit reagoivat ilmastonmuutokseen eri tavoin, yleistyksiä on vaikea tehdä (Harrington ym. 2001). Mallinnuksissa ei ole mahdollista huomioida kaikkia vaikuttavia tekijöitä. Ennusteiden ja mallien toimivuus riippuu siitä, miten hyvin voidaan arvioida hyönteisen menestymisen ja elossa säilyvyyden kannalta kriittisimmät tekijät. Sääolosuhteiden lisäksi myös viljelytoimien (mm. kylvöaika ja muokkaus) ja viljelykasvien muutokset heijastuvat tuhoeläinten runsauteen. Sama muutospaine kohdistuu paitsi tuhoeläimiin myös niiden luontaisiin vihollisiin (pedot ja loiset) ja lajien välisiin vuorovaikutussuhteisiin.

Tietovajetta on erityisesti talvikauden muutoksista ja pohjoisiin oloihin soveltuvista kriittisistä parametreista. Muutokset useamman trofiatason välisissä ja epäsuorissa vuorovaikutuksissa voivat olla arvaamattomia ja vaikeasti ennustettavia. Pitkien aikasarjojen ja seuranta-aineistojen arvo ja tärkeys korostuu ilmastonmuutokseen liittyvien mallien validoinnissa ja trendien havaitsemisessa (kuva 3).

\section{Kasvitaudit}

Lämpö- ja kosteusjaksojen lisääntyminen suosivat useimpia kasvitauteja ja pitenevä kasvukausi altistaa kasvit pidempään taudinaiheuttajille, mikä lisää torjunnan tarvetta. Eniten kasvitautien lajistoa tulee muuttamaan siirtyminen kevätmuotoisista viljoista ja öljykasveista syysmuotoihin. Lisääntyvä talviajan kasvipeitteisyys voi lisätä kasvitautiongelmia tarjoamalla talvehtimis- ja lisääntymispaikan taudeille, jotka eivät tällä hetkellä ole ongelmallisia. Siirtyminen kevennettyyn muokkaukseen on jo lisännyt satojätteissä elävien taudinaiheuttajien aiheuttamia tuhoja (Gregory ym. 2009).

Syysvehnän ja rukiin tyvilaikun (Oculimacula yallundae ja Oculimacula acuformis, anamorfi Pseudocercosporella herpothrichoides) merkitys tulee lisääntymään. Etelä-Skandinaviassa ja Brittein saarilla tauti aiheuttaa pahimmillaan $50 \%$ satotappioita ja sitä joudutaan säännönmukaisesti torjumaan kemiallisesti (Fitt ym. 1988, Sindberg ym. 1994). Tauti on sitä tuhovoimaisempi mitä enemmän lämpösummaa kertyy kylvön ja korrenkasvun alkamisen välisenä aikana syksyllä ja aikaisin keväällä (Bock ym. 2009).

Muuttuva ilmasto tulee suosimaan erityisesti viljojen ruoste- ja härmätauteja, jotka nykyisin ovat meillä melko satunnaisia. Ilmaston lämpeneminen voi lisäksi vaikuttaa härmän ja ruosteiden resistenssigeenien toimintaan viljoissa, niin että viileässä $\left(10^{\circ} \mathrm{C}\right)$ tehokkaat geenit eivät toimikaan lämpimissä $\left(25^{\circ} \mathrm{C}\right)$ oloissa (Gregory ym. 2009). Viime vuosilta on havaintoja, että ruosteet vioittavat syysviljoja jo syksyllä, mikä voi heikentää niiden talvenkestävyyttä. Syysmuotoisen ohran käyttöönotto mullistaisi ohranhärmän epidemioiden dynamiikan ja tekisi siitä meilläkin yhtä haitallisen, kuin se on nykyisin esim. Tanskassa (Bousset ym. 2002). Lisäksi mykotoksiineja tuottavien nykyisten ja uusien punahomelajien merkitys voi kasvaa ja muuttua hyvin vakavaksi, jos tulevaisuudessa maissia ja vehnää viljellään samoilla lohkoilla (Osborne ja Stein 2007).

Syysmuotoisten öljykasvien viljelyn lisääntyminen tuo uusia tautiongelmia. 1950-luvulla, jolloin syysmuotoisia öljykasveja viljeltiin laajemmin Suomessa talvituhosienet (Typhula spp.) aiheuttivat silloisille lajikkeille suurta tuhoa (Jamalainen 1954). Etelä-Ruotsissa syysmuotoisten öljykasvien pahimmaksi taudinaiheuttajaksi on muodostunut viime vuosina lakastumistauti (Verticillium longisporum) (Johansson ym. 2006), jota Suomen öljykasvipelloilla ei vielä juurikaan esiinny.

Lämpenevät säät ja lisääntyvä kosteus hyödyttävät monia bakteeritauteja, fytoplasmoja, viruksia ja niiden vektoreita, joista voi koitua lisääntyvää riesaa niin viljoille, perunalle kuin puutarhakasveille. Kauran kehälaikku (Pseudomonas syringae), joka on muualla hyvin tuhoisa bakteeritauti, on hiljakkoin levinnyt Suomeen (Jalli ym. 2008). Perunan tumma rengasmätä (Ralstonia solanacearum) voi milloin tahansa levitä Suomeen. Perunan tyvimätää aiheuttava bakteerilajisto (Dickeya spp.) on Suomessa, kuten muuallakin Euroopassa uudistunut tyystin ja muuttunut entistä aggressiivisemmaksi (Laurila ym. 2009).

\section{Rikkakasvit}

Rikkakasvilajistossa tapahtuvat muutokset ovat tähän mennessä ja jatkossakin ensisijaisesti seurausta pellon käytössä ja viljelytekniikassa tapahtuvista muutoksista. Tärkeimmät rikkakasvillisuuteen vaikuttavat ilmastotekijät ovat kasvukauden lämpö- ja sadeolot. Lämpimistä syksyistä ja leudommista talvista hyötyviä rikkakasvilajejakin on tyrkyllä. 
Maan muokkaustapa ja -ajoitus säätelevät kullakin pellolla vallitsevaa rikkakasvilajistoa. Kevätkylvöisten yksivuotisten viljelykasvien kasvustoissa viihtyvät samaan kasvurytmiin sopeutuneet lajit kuten jauhosavikka, pillikkeet ja tatarlajit. Jos sama pelto muokataan syksyllä ja kylvetään syysviljalle, runsaimpina esiintyvät rikkakasvilajit ovat todennäköisimmin saunakukka, peltolemmikki ja pelto-orvokki. Muokkausta kevennettäessä tai siitä kokonaan luovuttaessa heinämäiset rikkakasvit ja rikkayrteistä esim. voikukka, pujo ja linnunkaali runsastuvat. Suorakylvetyllä pellolla viihtyvät erityisesti piensiemeniset heinät, mm. timotei, nurmikka- ja natalajit. Vielä satunnaisesti esiintyviä mutta mahdollisia ongelmarikkaheiniä ovat syysviljoissa viihtyvät luoho ja kattarat.

Kasvien lämpötilavaatimukset vaihtelevat lajeittain. Reaktio vallitseviin lämpöoloihin alkaa jo siementen itämisvaiheesta ja päättyy kun uusien siementen kehittymiseen tarvittavaa tehoisaa lämpösummaa on kertynyt riittävästi. Ilmaston merkittävän lämpenemisen myötä Suomeen asettuu tyypillisten $\mathrm{C}_{3}$-kasviemme rinnalle kasveja, joiden tehokkaampi $\mathrm{C}_{4}$-yhteyttämismekanismi antaa kilpailuedun muita lajeja vastaan. Tällaisia lajeja ovat viljelykasveista mm. maissi ja maissikasvustoissa viihtyvistä rikkakasveista kananhirssi (Echnichloa crus-galli) ja viherrevonhäntä (Amaranthus retroflexus). Hallattoman kauden pituus kesällä on ilmastotekijä, jonka perusteella voi arvioida näiden $\mathrm{C}_{4}$-kasvien menestymistä Suomessa.

Kasvinsuojelun kannalta rikkakasvillisuuden muutoksen suunta on kohti hankalampia lajeja, joiden kemialliseen torjuntaan tarvitaan nykyisen herbisidivalikoiman tehokkaimpia tuotteita tai kokonaan uusia tehoaineita. Heinämäisiin lajeihin tehoava glyfosaatti ei yksinään ole kestävä ratkaisu lisääntyviin haasteisiin, sillä erityisesti siemenlevintäisiin heiniin voi kehittyä glyfosaattia kestäviä kantoja. Jos syyskylvöiset kasvit yleistyvät ilmastoltaan lämpenevässä Suomessa, syysitoiset rikkakasvit ja erityisesti rikkaheinät runsastuvat siinä määrin, että ne joudutaan torjumaan kemiallisesti jo syksyllä. Torjuntatarpeen muutos lisää kasvinsuojeluaineiden käyttöä ja ympäristöriskiä. Haasteellisempi rikkakasvillisuus pakottaa miettimään tarkemmin myös viljelykiertoja rikkakasviongelmien hallitsemiseksi.

\section{Johtopäätökset}

Ilmaston muutos lisää kasvinsuojeluriskejä ja niiden torjunnasta johtuvia ympäristöriskejä monella tavalla. Riskien hillintä perustuu kotimaisen ja terveen lisäysmateriaalin käyttöön eli terveen kasvimateriaalin tuotantokapasiteetti on osa kansallispääomaa, joka pitää säilyttää. Samoin taudinkestävien lajikkeiden jalostus pitää varmistaa kansallisin varoin. Riskimuutosten seurantaa varten tarvitaan systemaattinen tarkkailujärjestelmä ja tehokas tiedonvälitys. Panostus biologiseen torjuntaan ja ekosysteemipalvelujen tuntemiseen on välttämätöntä, jos halutaan välttää kemiallisen torjunnan kasvu ja kasvinsuojelusta (tai sen epäonnistumisesta) aiheutuvat ympäristöriskit. Viljelyjärjestelmien kehittämisessä ja maankäytössä on painopiste siirrettävä kesäkaudesta talveen, koska talvikauden biologiset prosessit muuttuvat eniten. Onnistunut sopeutuminen talvikauden muutoksiin ja ekosysteemipalvelujen tehokas hyödyntäminen ratkaisevat riskienhallinnan kokonaisuuden.

\section{Kirjallisuus}

Bock, C. H., Wan, A.M. \& Fitt, B.D.L. 2009. Development of Oculimacula yallundae and O. acuformis (eyespot) lesions on stems of winter wheat in relation to thermal time in UK. Plant Pathology 58:12-22.

Bousset, L., Hovmøller, M.S., Caffier, V., de Vallavielle-Pope, C. \& Østergård, H. 2002. Observed and predicted changes over eight years in frequency of barley powdery mildew avirulent to spring barley in France and Danmark. Plant Pathology 51:33-44.

Carter, T., Hakala, K., Kaukoranta,T., Kleemola, J., Laurila, H., Mela, T., Pehu, E., Saarikko, R., Tiilikkala, K. 1996. Maatalous. In: Kuusisto Esko, Kauppi Lea ja Heikinheimo Pirkko (toim.). Ilmastonmuutos ja Suomi. Helsinki: Yliopistopaino ja Suomen Akatemia. p. 127-143. (Luvun Maatalous toimittajat: Timothy Carter ja Riitta Saarikko).

Commission of the European communities 2006. Thematic strategy on the sustainable use of Pesticides. Viitattu 5.11.2007. Saatavissa internetissä: http://ec.europa.eu/environment/ppps/pdf/com_2006_0372.pdf

Cocu, N., Harrington, R., Rounsevell, M.D.A., Worner, S.P., Hulle, M. and the EXAMINE project participants 2005. Geographical location, climate and land use influences on the phenology and numbers of the aphid, Myzus persicae, in Europe. Journal of Biogeography 32:615-632.

The European Parliament and the Council. 2009a. Establishing a framework for community action to achieve the 
sustainable use of pesticides. Directive of the European Parliament and the Council.

The European Parliament and the Council 2009b. Regulation of the European Parliament and the Council concerning the placing of plant protection products on the market and repealing Council Directives 79/117/EEC and 91/414/EEC.

Evira 2009. Tilastotietoa Kasvinsuojeluaineiden myynti Suomessa / Plant protection product sales in Finland Viitattu 23.11. 2009. Saatavissa internetissä:

http://www.evira.fi/portal/fi/kasvintuotanto_ja_rehut/kasvinsuojeluaineet/tilastotietoa/

FAO 2006. International standards for phytosanitary measures no. 11. pest risk analysis for quarantine pests including analysis of environmental risks and living modified organisms. FAO Rome pp. 114-138.

Fitt, B.D.L, Goulds, A. \& Polley, R.W. 1988. Eyespot (Pseudocercosporella herpothrichoides) epidemiology in relation to prediction of disease severity and yield loss in winter wheat - a review. Plant Pathology 37: 311-328.

Gregory, P.J., Johnson, S.N., Newton. A.C. \& Ingram, J.S.I. 2009. Integrating pests and pathogens into the climate change/food security debate. Journal of Experimental Botany 60:2827_2838.

Hannukkala, A., Kaukoranta, T., Lehtinen, A., Rahkonen, A. 2007. Late-blight epidemics on potato in Finland, 1933-2002; increased and earlier occurrence of epidemics associated with climate change and lack of rotation. Plant pathology 56, 1: 167-176.

Harrington, R., Fleming, R.A. \& Woiwod, A.P. 2001. Climate change impacts on insect management and conservation in temperate regions: can they be predicted? Agricultural and Forest Entomology 3: 233-240.

Harrington, R. 2007. Viruses, vectors, host plants and environment: From complexity to control. In: NJF Seminar 402 : Virus vector management in a changing climate, preliminary report, Kristianstad, Sweden, 9-11 October 2007. p. 9-11.

Hart A.J., Bale, J.S. \& Fenlon, J.S. 1997. Development threshold, day-degree requirements and voltinism of the aphid predator Episyrphus balteatus (Diptera: Syrphidae). Annales Applied Biology 130: 427-437.

Jalli, M., Pietilä, L.\& Kahala, M. 2008. Lehtibakterioosi aiheuttaa kauran kehälaikkua. Kasvinsuojelulehti 2: 50-51. Jamalainen, E.E., 1954. Overwintering of cultivated plants under snow. Fao Plant Protection Bulletin 11:102 - 105. Johansson, A., Goud, J-K.C. \& Dixelius, C. 2006. Plant host range of Verticillium longisporium and microsclerotia density in Swedish soils. European Journal of Plant Pathology 114:139 - 149.

Kaukoranta T. 1996 . Impact of global warming on potato late blight: risk, yield loss and control. Agricultural and Food Science in Finland 5, $3: 311-327$.

Laurila, J., Ahola, V., Lehtinen, A., Joutsjoki, T., Hannukkala, A., Rahkonen, A., Pirhonen, M. 2008. Characterization of Dickeya strains isolated from potato and river water samples in Finland. European journal of plant pathology 122, 2: 213-225.

Lindgren, E. \& Gustafson, R. 2007. Tick-borne encephalitis in Sweden and climate change. The Lancet, Volume 358, Issue 9275, Pages 16-18.

Mela, T., Carter, T., Hakala, K., Hannukkala, A., Kaukoranta, T., Laurila, H., Niemi, K., Saarikko, R.,.

Osborne, L.E. \& Stein, J.M. 2007. Epidemiology of Fusarium head blight on small-grain cereals.. International Journal of Food Microbiology 119:103-108.

Päivinen S. 2007. Ilmastonmuutoksen vaikutus lehti- ja havununnan (Lymantria dispar ja Lymantria monacha) leviämiseen Suomeen. Kasvinsuojelulehti 40, 3, 72 - 75.

Ruuttunen, P., Laitinen, P. 2008. Torjunta-aineiden toistuvan käytön ympäristöriskit perunanviljelyssä. Maa- ja elintarviketalous 119: $190 \mathrm{~s}$. [Url] Verkkojulkaisu päivitetty 2.4.2008 .

Salonen, J., Bromand, B., Jørgensen, L.N. 2001. Crop production conditions in the northern European region with a special reference to crop protection. DIAS report Plant Production no. 59. $125 \mathrm{p}$.

Sindberg, S., Munk, L., \& Schulz, H. 1994, Tapesia yallundae, the teleomorph of Pseudocercosorella herpotrichoides observed for the 1st time in Denmark. Zeitschrift für Pflanzenkrankheiten und Pflanzenschutz 101: 316-320.

Sutherst, R.W., Maywald, G.F., Bottomley, W. \& Bourne A. 2004. CLIMEX for Windows v2. Users guide. CSIRO Publications.

Tiilikkala, K. 1991. Impact of climate and agricultural practices on the pest status of Heteroderoidea nematodes in Finland. 43 p + 62 p. Diss. : Helsinki: University of Helsinki, 1991.

Tiilikkala, K. 1996. The effects of climatic change on crop production: results of a five-year research project. In: Jaana Roos (Ed.). The Finnish Research Programme on Climate Change : Final report. Publications of the Academy of Finland 4/96: 324-336.

Tiilikkala, K., Hannukkala, A. \& Ooperi, S. 2008. Ilmaston muutos lisää kasvinsuojelun riskejä. In: Toim. Anneli Hopponen. Maataloustieteen Päivät 2008, 10.-11.1.2008 [: esitelmät ja posterit]. Suomen maataloustieteellisen seuran tiedote 23: 6 p. [ Url] Julkaistu 9.1.2008

Vanhanen, H.M. 2008. Invasive insects in Europe - the role of climate change and global trade. Dissertationes Forestales 57. 33p. Available at http://www.metla.fi/dissertationes/df57.htm. 